\section{Bactericidal Effect of Calcium Oxide and Calcined Shell Calcium on Legionella pneumophila}

\author{
Takashi Asada, ${ }^{*}, a$ Masayoshi Omichi, ${ }^{b}$ \\ Tomoko Kimura, ${ }^{b}$ and Kikuo Oikawa ${ }^{a}$
}

${ }^{a}$ Department of Environmental Chemistry, Niigata College of Pharmacy, 5-13-2 Kamishinei-cho, Niigata 950-2081, Japan and ${ }^{b}$ Chiba City Institute of Health and Environment, 1-3-9 Saiwai-cho, Mihama-ku, Chiba 261-0001, Japan

(Received February 15, 2001; Accepted April 24, 2001)

Both calcined shell calcium, which was recently reported to have bactericidal effects on Escherichia coli 0157 : H7, Pseudomonas aeruginosa, and Staphylococcus aureus, and calcium oxide, which is the main component in calcined shell calcium, were examined as a bactericide against Legionella species. A calcined shell calcium solution of $0.025 \%$ or above reduced $L$. pneumophila counts from the original $7.0 \times 10^{6} \mathrm{CFU} /$ $\mathrm{ml}$ to less than $300 \mathrm{CFU} / \mathrm{ml}$ after an incubation period of $1 \mathrm{hr}$. In water samples taken from the cooling tower of a prefabricated house, a calcined shell calcium solution of $0.05 \%$ or above reduced $L$. pneumophila counts to less than $10 \mathrm{CFU} / \mathrm{ml}$ after an incubation period of $1 \mathrm{hr}$. There was no difference between the bactericidal effects of the calcined shell calcium manufactured from the shells of surf clams and that manufactured from oysters; surf clams and oysters are equally effective. Calcium oxide also showed similar bactericidal effects against $L$. pneumophila, and thus we believe that the effect is not specific to calcined shell calcium, but rather to effects caused by the alkalinity of calcium oxide. The use of calcium oxide or calcined shell calcium as a bactericidal agent against Legionella species in the cooling tower water of hotels or other buildings is therefore expected.

Key words L Legionella pneumophila, cooling tower water, calcined shell calcium, calcium oxide, bactericidal effect

\footnotetext{
*To whom correspondence should be addressed: Department of Environmental Chemistry, Niigata College of pharmacy, 5-132 Kamishinei-cho, Niigata 950-2081, Japan. Tel.: +81-025-2681207; Fax: +81-205-268-1281; E-mail: oikawa@niigata-pharm. ac.jp
}

\section{INTRODUCTION}

In the natural environment, Legionella species exist in the hydrosphere (i.e., moist soil, ponds, marshes, lakes, or rivers). In artificial environments, Legionella species have been reported in the cooling tower water of buildings or hotels, ${ }^{1)}$ water-supply systems or heated-water systems, ${ }^{2)}$ 24-hr circulatory baths,${ }^{3)}$ humidifiers, ${ }^{4)}$ decorative fountains, ${ }^{5)}$ and hot spring baths. ${ }^{6}$ ) The existence of Legionella species in a 24-hr circulatory bath caused on outbreak of Legionnaires' disease in a Tokyo home for senior citizens in May 1998. One patient died of pneumonia caused by the Legionella species. Cases of infection by Legionella species were also reported in water-supply systems or heated-water systems, ${ }^{7)}$ the cooling tower water of buildings or hotels, ${ }^{8)}$ whirlpool spas, ${ }^{9)}$ humidifiers, ${ }^{10)}$ decorative fountains, ${ }^{11)}$ and hot spring baths. ${ }^{12)}$

After these incidents, a counterplan for the prevention of Legionnaires' disease in buildings etc. (No. 1679, November $26^{\text {th }}$, 1999) was prescribed by the Japanese Ministry of Health and Welfare's Environmental Health Bureau. Among the measures prescribed were the disinfection, cleaning, and exchange of water in the cooling towers of buildings or hotels, as well as in water-supply systems, heatedwater systems, 24-hr circulatory baths, respiratorhumidifiers, decorative fountains, and hot spring baths.

Furthermore, in November 1999, the Building Management Education Center proposed that Legionella species must be controlled according to new guidelines to prevent Legionnaires' disease through the use of an infection factor grading system. When inspection for bacteria proves positive, disinfection and cleaning must be carried out to reduce Legionella species to an undetectable amount (less than $10 \mathrm{CFU} / 100 \mathrm{ml}$ ). Furthermore, it is required that agents to sterilize Legionella species should be infused in cooling tower water to prevent outbreaks of Legionnaires' disease.

At present, although methods such as bactericide by chlorine ${ }^{13)}$ bactericidal agents, ${ }^{14)}$ and heat, ozone, or UV light ${ }^{15)}$ have been reported, there is no established method for the sterilization of Legionella species. In this study, therefore both calcined shell calcium, which was reported to have bactericidal effects on Escherichia coli $\mathrm{O} 157$ : H7, Pseudomonas aeruginosa, and Staphylococcus aureus, ${ }^{16,17)}$ and calcium oxide, which is a main component in calcined shell calcium, were examined as a bactericide 
against Legionella species.

\section{MATERIALS AND METHODS}

Calcined Shell Calcium and Calcium Oxide — - In this study, freely available calcined shell calcium, which is manufactured from surf clams or oysters as a food additive, was used. Calcium oxide of analytical grade was purchased from Wako Pure Chemical Industries, Ltd. (Osaka, Japan).

Determination of L. pneumophila Counts - At present, because no official method for the determination of Legionella species counts exists in Japan, ${ }^{18)}$ the culture method using buffered charcoal-yeast extract (BCYE $\alpha$ ) agar medium (used widely for the determination of L. pneumophila counts) was adopted in this study. The test organism was $L$. pneumophila serogroup 1 taken from cooling tower water.

\section{Evaluation of Bactericidal Effects -}

1. Calcined shell calcium solutions and calcium oxide solutions of $0,0.005,0.025,0.05,0.1,0.5$, and $1.0 \mathrm{w} / \mathrm{v} \%$ were prepared with $200 \mathrm{ml}$ of distilled water. In the same way, $0,0.005,0.025,0.05,0.1$, and $0.5 \mathrm{w} / \mathrm{v} \%$ calcined shell calcium solutions and calcium oxide solutions were prepared with $100 \mathrm{ml}$ of cooling water taken from a prefabricated house. 2 . The test organisms were added to physiological saline to make a test suspension of McFarland 5.

3 . One milliliter of the test suspension prepared at stage 2 was added to the $200 \mathrm{ml}(100 \mathrm{ml}$ for cooling tower water) of each calcined shell calcium solution and calcium oxide solution.

4. After the addition of the test suspension, both the calcined shell calcium solution and calcium oxide solution were stirred well. After the addition of the test suspension, each solution was incubated at room temperature and samples were taken after intervals of 1, 24, and $48 \mathrm{hr}$. Serial dilutions of the sample were made and $0.1 \mathrm{ml}$ of each dilution was spread on agar plates. In the case of the $0 \%$ calcined shell calcium solution and calcium oxide solution, sampling also was carried out before incubation.

5. Colonies of L. pneumophila were counted after incubation periods of 7 days. The original counts were determined from the serial dilutions of $0 \%$ solutions before incubation.
Table 1. Bactericidal Effects of Calcined Shell Calcium Solution against $L$. pneumophila

\begin{tabular}{lccc}
\hline \hline \multirow{2}{*}{$\begin{array}{l}\text { Sample } \\
\text { concentration }\end{array}$} & \multicolumn{3}{c}{$\begin{array}{c}\text { L. pneumophila count } \\
(\mathrm{CFU} / \mathrm{ml})\end{array}$} \\
\cline { 2 - 4 }$\%$ & After 1 hr & After 24 hr & After 48 hr \\
\hline 1.000 & $<300$ & $<300$ & $<300$ \\
0.500 & $<300$ & $<300$ & $<300$ \\
0.100 & $<300$ & $<300$ & $<300$ \\
0.050 & $<300$ & $<300$ & $<300$ \\
0.025 & $<300$ & $<300$ & $<300$ \\
0.005 & 41000 & $<300$ & $<300$ \\
\hline \multicolumn{2}{c}{ Time 0: 7000000 CFU/ml }
\end{tabular}

Table 2. Bactericidal Effects against L. pneumophila of Calcined Shell Calcium Prepared with Stabilized Cooling Tower Water

\begin{tabular}{lcccc}
\hline \hline $\begin{array}{l}\text { Sample } \\
\text { concentration }\end{array}$ & \multicolumn{4}{c}{$\begin{array}{l}\text { L. pneumophila } \\
(\mathrm{CFU} / \mathrm{ml})\end{array}$} \\
\cline { 2 - 5 }$\%$ & 0 time & After 1 hr & After 24 hr & After 48 hr \\
\hline 0 & $7.9 \times 10^{5}$ & $7.7 \times 10^{5}$ & $8.7 \times 10^{5}$ & $7.2 \times 10^{5}$ \\
0.005 & $7.9 \times 10^{5}$ & $6.7 \times 10^{5}$ & $3.0 \times 10^{5}$ & $2.2 \times 10^{5}$ \\
0.025 & $7.9 \times 10^{5}$ & $<10$ & $<10$ & $<10$ \\
0.050 & $7.9 \times 10^{5}$ & $<10$ & $<10$ & $<10$ \\
0.100 & $7.9 \times 10^{5}$ & $<10$ & $<10$ & $<10$ \\
\hline
\end{tabular}

\section{RESULTS}

\section{Bactericidal Effects of Calcined Shell Calcium Solution against $L$. pneumophila (Table 1)}

A calcined shell calcium solution of $0.025 \%$ or above reduced $L$. pneumophila counts from the original $7.0 \times 10^{6} \mathrm{CFU} / \mathrm{ml}$ to less than $300 \mathrm{CFU} / \mathrm{ml}$ after an incubation period of $1 \mathrm{hr}$. L. pneumophila counts did not increase after incubation periods of 24 or $48 \mathrm{hr}$. A $0.005 \%$ solution reduced counts to about $1 / 100$ of the original counts after an incubation period of $1 \mathrm{hr}$ and to less than $300 \mathrm{CFU} / \mathrm{ml}$ after an incubation period of $24 \mathrm{hr}$. L. pneumophila counts did not increase after an incubation period of $48 \mathrm{hr}$.

\section{Bactericidal Effects of Calcined Shell Calcium Prepared with Cooling Tower Water against $L$. pneumophila}

Bactericidal effects were tested in cooling tower water taken from a prefabricated house. The calcined shell calcium was prepared in both sterilized and nonsterilized cooling tower water, because it was expected that various bacteria were present.

Table 2 shows the bactericidal effects against $L$. pneumophila of calcined shell calcium prepared with 
sterilized cooling tower water. In sterilized cooling tower water, a calcined shell calcium solution of $0.025 \%$ or above reduced L. pneumophila counts from the original $7.9 \times 10^{5} \mathrm{CFU} / \mathrm{ml}$ to less than $10 \mathrm{CFU} / \mathrm{ml}$ after an incubation period of $1 \mathrm{hr}$. $L$. pneumophila counts did not increase after incubation periods of $24 \mathrm{or} 48 \mathrm{hr}$.

A $0.005 \%$ solution resulted in a slight decrease in L. pneumophila counts, and this decrease was therefore not attributable to bactericidal effects. In the control $(0 \%)$ solution, few changes were observed at all intervals up to $48 \mathrm{hr}$, and the changes were therefore not attributable to bacterial effects.

Table 3 shows the bactericidal effects against $L$. pneumophila of calcined shell calcium prepared with nonsterilized cooling tower water. The bacterial counts in nonsterilized cooling tower water were as follows: Legionella counts $4400 \mathrm{CFU} / 100 \mathrm{ml}$; total counts of microorganisms were $51 \mathrm{CFU} / \mathrm{ml}$; and coliform was not detected. In nonsterilized cooling water, a calcined shell calcium solution of $0.05 \%$ or above reduced $L$. pneumophila counts from the original $8.2 \times 10^{5} \mathrm{CFU} / \mathrm{ml}$ to less than $10 \mathrm{CFU} / \mathrm{ml}$ after an incubation period of $1 \mathrm{hr}$. L. pneumophila counts did not increase after incubation periods of 24 or $48 \mathrm{hr}$. A $0.025 \%$ solution reduced L. pneumophila counts to about $1 / 100$ of the original counts after an

Table 3. Bactericidal Effects against L. pneumophila of Calcined Shell Calcium Prepared with Nonsterilized Cooling Tower Water

\begin{tabular}{|c|c|c|c|c|}
\hline \multicolumn{2}{|c|}{$\begin{array}{l}\text { Sample } \\
\text { concentration }\end{array}$} & \multicolumn{2}{|c|}{$\begin{array}{l}\text { L.pneumophila } \\
\qquad(\mathrm{CFU} / \mathrm{ml})\end{array}$} & \multirow[b]{2}{*}{ After $48 \mathrm{hr}$} \\
\hline$\%$ & 0 time & After $1 \mathrm{hr}$ & After $24 \mathrm{hr}$ & \\
\hline 0 & $8.2 \times 10^{5}$ & $1.3 \times 10^{6}$ & $7.3 \times 10^{5}$ & $6.0 \times 10^{5}$ \\
\hline 0.005 & $8.2 \times 10^{5}$ & $1.1 \times 10^{6}$ & $5.5 \times 10^{5}$ & $4.6 \times 10^{5}$ \\
\hline 0.025 & $8.2 \times 10^{5}$ & $7.9 \times 10^{4}$ & $<10$ & $<10$ \\
\hline 0.050 & $8.2 \times 10^{5}$ & $<10$ & $<10$ & $<10$ \\
\hline 0.100 & $8.2 \times 10^{5}$ & $<10$ & $<10$ & $<10$ \\
\hline
\end{tabular}

incubation period of $1 \mathrm{hr}$ and to less than $10 \mathrm{CFU} / \mathrm{ml}$ after $24 \mathrm{hr}$. L. pneumophila counts did not increase after an incubation period of $48 \mathrm{hr}$. A $0.005 \%$ solution resulted in only a slight decrease in $L$. pneumophila counts, and this decrease was therefore not attributable to bactericidal effects. In the control $(0 \%)$ solution, few changes were observed at all intervals up to $48 \mathrm{hr}$, and these changes were therefore not attributable to bactericidal effects.

\section{Comparison of the Bactericidal Effects of Calcium Oxide and Those of Calcined Shell Calcium}

Because a main component of calcined shell calcium is calcium oxide, the bactericidal effects of calcium oxide against $L$. pneumophila were tested. Calcined shell calcium prepared from surf clams or from oysters was also tested. The results are shown in Table 4. A $0.005 \%$ calcined shell calcium solution both from surf clams and from oysters reduced L. pneumophila counts to $5700 \mathrm{CFU} / \mathrm{ml}$ and $5300 \mathrm{CFU} / \mathrm{ml}$, respectively, after an incubation period of $1 \mathrm{hr}$ and to less than $10 \mathrm{CFU} / \mathrm{ml}$ from the original $4.3 \times 10^{5} \mathrm{CFU} / \mathrm{ml}$ after an incubation period of $24 \mathrm{hr}$. L. pneumophila counts did not increase after an incubation period of $48 \mathrm{hr}$. Similarly, a $0.005 \%$ calcium oxide solution reduced $L$. pneumophila counts from the original $4.3 \times 10^{5} \mathrm{CFU} / \mathrm{ml}$ to $5000 \mathrm{CFU} / \mathrm{ml}$ after an incubation period of $1 \mathrm{hr}$ and to less than $10 \mathrm{CFU} / \mathrm{ml}$ after an incubation period of $24 \mathrm{hr}$. L. pneumophila counts did not increase after an incubation period of $48 \mathrm{hr}$.

\section{DISCUSSION}

In the experiments on the bactericidal effects against $L$. pneumophila, $0.025 \%$ calcined shell calcium was able to reduce $L$. pneumophila counts by four digits, and the bactericidal effects of calcined shell calcium against $L$. pneumophila was thus con-

Table 4. Comparison of the Bactericidal Effects of Calcium Oxide and Those of Calcined Shell Calcium

\begin{tabular}{lccccccccc}
\hline \hline $\begin{array}{l}\text { Sample } \\
\text { concentration }\end{array}$ & \multicolumn{3}{c}{$\begin{array}{c}\text { L. pneumophila count (CFU/ml) } \\
\text { Oyster }\end{array}$} \\
\cline { 2 - 10 }$\%$ & After 1 hr & After 24 hr & After 48 hr & After 1 hr & After 24 hr & After 48 hr & After 1 hr & After 24 hr & After 48 hr \\
\hline 0 & 490000 & 240000 & 200000 & 490000 & 240000 & 200000 & 490000 & 240000 & 200000 \\
0.100 & $<10$ & $<10$ & $<10$ & $<10$ & $<10$ & $<10$ & $<10$ & $<10$ & $<10$ \\
0.050 & $<10$ & $<10$ & $<10$ & $<10$ & $<10$ & $<10$ & $<10$ & $<10$ & $<10$ \\
0.025 & $<10$ & $<10$ & $<10$ & $<10$ & $<10$ & $<10$ & $<10$ & $<10$ & $<10$ \\
0.005 & 5700 & $<10$ & $<10$ & 5300 & $<10$ & $<10$ & 5000 & $<10$ & $<10$ \\
\hline
\end{tabular}

L. pneumophila counts at time $0: 430000 \mathrm{CFU} / \mathrm{ml}$. 
firmed. Because a $0.025 \%$ calcined shell calcium solution has a strong alkalinity ( $\mathrm{pH} 12),{ }^{17)}$ Legionella species that mainly grow at $\mathrm{pH}$ of $6.8-6.9^{5)}$ cannot exist. In experiments utilizing cooling tower water from a prefabricated house, $L$. pneumophila counts were $4400 \mathrm{CFU} / 100 \mathrm{ml}$. This is equivalent to the $10^{2}-10^{4} \mathrm{CFU} / 100 \mathrm{ml}$ Legionella species counts reported $^{1)}$ in cooling tower water containing no chemical agents. Calcined shell calcium solution levels of $0.025 \%$ can reduce $L$. pneumophila counts to less than $10 \mathrm{CFU} / \mathrm{ml}$ after an incubation period of only $1 \mathrm{hr}$, and these bactericidal effects were confirmed in actual cooling tower water. Even if bacteria other than L. pneumophila existed in the nonsterilized cooling tower water, sufficient bactericidal effects were confirmed in the $0.05 \%$ calcined shell calcium solution. This effect was comparable to the effects of sodium hypochlorite solution, which corresponds to a level of free residual chlorine of $0.4 \mathrm{mg} / 1 .{ }^{13)}$ Taking into account the new governmental guidelines (i.e., when a test for Legionella species proves positive, the cooling tower must be cleaned and disinfected and Legionella species counts must be reduced to an undetectable amount [10 CFU/100 ml] to prevent Legionnaires' disease) as proposed by the Building Management Education Center, we consider calcined shell calcium useful as a bactericidal agent against $L$. pneumophila in cooling tower water. Calcium oxide, which is known to be a disinfectant, showed similar bactericidal effects against $L$. pneumophila. It can therefore be concluded that the bactericidal effects were not specific to calcined shell calcium but rather result from the alkaline effects of calcium oxide. Furthermore, the shells of both surf clams and oysters have similar bactericidal effects, so it can be concluded that there is no difference in the bactericidal effects of either type of shell. Sufficient bactericidal effects of both calcined shell calcium and calcium oxide were confirmed against Legionella species in actual cooling tower water. Therefore we concluded that these calcium preparations could be of practical use in sterilizing Legionella species in cooling towers.

\section{REFERENCES}

1) Agata, K. and Hironaka, T. (1994) Distribution of Legionellae in Cooling Tower Water in Japan. Kansenshogaku Zasshi, 68, 421-423.

2) Furuhata, K., Takayanagi, T., Danno, N., Okada, S. and Kiya, F. (1994) Contamination of hot water supply in office buildings by Legionella pneumophila and some countermeasures. Nippon Koshu Eisei Zasshi, 41, 1073-1083.

3) Li, N., Aoyama, T., Hori, H. and Ezaki, T. (1997) Isolation of Legionella pneumophila from $24 \mathrm{hr}-$ home bath water and an eradication trial of the bacteria from the bath. Kansenshogaku Zasshi, 71, 763-769.

4) Agrawal, L., Dhunjibhoy, K. R. and Nair, K. G. (1991) Isolation of Legionella pneumophila from patients of respiratory tract disease \& environmental samples. Indian J. Med. Res., 93, 364-365.

5) Furuhata, K. (1995) Bacteria of Legionella. Mizu, 37, 39-37.

6) Yabuuchi, E., Wang, L., Arakawa, M. and Yano, I. (1994) Distribution of Legionellae in Hot Spring Bath Water in Japan. Kansenshogaku Zasshi, 68, 549-551.

7) Visca, P., Goldoni, P., Luck, P. C., Helbig, J. H., Cattani, L., Giltri, G., Bramati, S. and Castellani Pastoris, M. (1999) Multiple types of Legionella pneumophila serogroup 6 in a hospital heated-water system associated with sporadic infections. J. Clin. Microbiol., 37, 2189-2196.

8) Yabuuchi, E., Mori, M., Saito, A., Kishimoto, T., Yoshizawa, S., Arakawa, M., Kinouchi, R., Wang, L., Furuhata, K. and Koide, M. (1995) An outbreak of Pontiac fever due to Legionella pneumophila serogroup 7. II. Epidemiological aspects. Kansenshogaku Zasshi, 69, 654-665.

9) Luttichau, H. R., Vinther, C., Uldum, S. A., Moller, J., Faber, M. and Jensen, J. S. (1998) An outbreak of Pontiac fever among children following use of a whirlpool. Clin. Infect. Dis., 26, 1374-1378.

10) Spitalny, K. C., Vogt, R. L., Orciari, L. A., Witherell, L. E., Etkind, P. and Novick, L. F. (1984) Pontiac fever associated with a whirlpool spa. Am.J. Epidemiol., 120, 809-817.

11) Hlady, W. G., Mullen, R. C., Mintz, C. S., Shelton, B. G., Hopkins, R. S. and Daikos, G. L. (1993) Outbreak of Legionnaire's disease linked to a decorative fountain by molecular epidemiology. Am. J. Epidemiol., 138, 555-562.

12) Shiota, R., Takeshita, K., Yamamoto, K., Imada, K., Yabuuchi, E. and Wang, L. (1995) Legionella pneumophila serogroup 3 isolated from a patient of pneumonia developed after drowning in bathtub of a hot spring spa. Kansenshogaku Zasshi, 69, 13561364.

13) Yabuuchi, E., Wang, L., Yamayoshi, T., Arakawa, M. and Yano, I. (1995) Bactericidal effect of chlorine on strains of Legionella species. Kansenshogaku Zasshi, 69, 151-157.

14) Kasai, J., Ando, F. and Kuwashima, M. (1989), Isolation of Legionella spp. from cooling tower 
water and the effect of microbicides. Rinsho Byori, 37, 918-922.

15) Muraca, P., Stout, J. E. and Yu, V. L. (1987), Comparative assessment of chlorine, heat, ozone, and UV light for killing Legionella pneumophila within a model plumbing system. Appl.Environ. Microbiol., 53, 447-453.

16) Isshiki, K., Suhara, H., Mizuuchi, K. and Tokuoka, K. (1994), Effectiveness of calcium preparation to control microbial growth in food. Nippon Shokuhin
Kogyo Gakkaishi, 41, 135-140.

17) Oikawa, K., Asada, T., Yamamoto, K., Wakabayashi, H., Sasaki, M., Sato, M. and Matsuda, J. (2000) Antibacterial activity of calcined shell calcium prepared from wild surf clam. J. Health Sci., 45, 98-103.

18) Furuhata, K. (1999) On revised "the new guideline to prevent Legionnaires' disease." J. Antibact. Antifung. Agents, 27, 533-539. 